\title{
ROLE OF PUBLIC EXPENDITURE IN ECONOMIC GROWTH: ECONOMETRIC EVIDENCE FROM KOSOVO 2002-2015
}

\author{
Lekë PULA ${ }^{1}$, Alban ELSHANI ${ }^{2}$ \\ ${ }^{1,2}$ University of Prishtina, Prishtina, Kosovo \\ Corresponding author's e-mail: leke.pula@uni-pr.edu
}

\begin{abstract}
The aim of the study is to examine the impact of public expenditure on economic growth of Kosovo. Time series data span for the period of time 2002-2015. The structure of the econometric model is built on Keynesian theories and endogenous growth model. The model estimation is performed only after implementing the Augmented Dickey-Fuller (ADF) Unit Root test to estimate if time series are stationary. Several tests have been implemented to determine model validity. The model has met all the assumptions of statistical tests: error term residuals have a normal distribution (Jarque-Bera test), there is no auto-correlation between variables (Breusch-Godfrey Serial test), and error variances are constant, known as the principle of homoscedasticity (BreuschPagan-Godfrey test). Gross domestic product is used as a dependent variable in the model, while public expenditure $(G)$, foreign direct investment $(F D I)$, export $(E X P)$ and total budget revenue (TrTax) are used as the endogenous variables. The study results have revealed that there is a positive and statistically significant effect of public expenditures and exports on economic growth. Total budget revenue has a positive impact on economic growth but this has not been proved to be statistically significant. The authors of the research have also found out that $F D I$ is negative and statistically insignificant.
\end{abstract}

Keyword: Economic growth, FDI, Kosovo, public expenditure.

\section{INTRODUCTION}

Government functions and activities are important because they provide a public good and minimise some of the imperfections and failures of the market mechanism. These functions and activities can be executed by utilising public spending instruments. Public spending is considered to be an important tool of fiscal policy, which includes all consumer goods, investment payments and redistribution of the income. The government uses them to speed up economic growth by increasing the demand for productive public goods (Slemrod, 1995). Stiglitz and Atkinson (1980) states that public spending should create favourable conditions for economic development through improving and maintaining the investment climate, and achieving the main objectives of economic growth. According to Tanzi and Zee (1997), fiscal policy is implemented by using fiscal instruments (taxes and expenditures) to influence the economic system in order to maximise economic well-being with the main objective of stimulating the long-term economic growth. 
The relationship between public spending and economic growth is one of the most controversial topics both theoretically and empirically, and has created a great deal of interest among economists and policymakers. Literature addresses this issue abundantly; it has also fuelled controversy as to the direction of causality, creating two different and contrasting views. One view, called the Wagner law, states that economic growth is causing public spending to grow, considering public spending endogenous, a view which has strong support among researchers Peacock \& Wiseman, (1979); Sinha, 1998; Bağdigen \& Çetintaş, 2004; Maingi, 2017). On the other hand, the Keynesian school's view argues that public spending is considered an exogenous factor and used as an instrument to influence the economic growth. Relying on this assumption, many developed and developing countries have used fiscal policy as an instrument for promoting and developing economic growth through the multiplier effect (King, 2012).

Based on Keynesian views, Kosovo uses public spending as one of the most important fiscal policy instruments to ensure equality and influence macroeconomic parameters in order to provide support to the private sector and, at the same time, to stimulate economic growth. Consequently, the careful use of this economic instrument remains one of the priorities of special importance for policymakers, since fiscal policy is the only instrument of economic policy in Kosovo.

Public expenditures in Kosovo are classified according to these two categories: economic classification and functional classification. These classifications are made on the basis of international guidelines and government finance statistics of the IMF (IMF, 2015). Under the economic classification, public spending is divided into current and capital expenditures. The graph below shows the public expenditures by economic categories in relation to GDP.

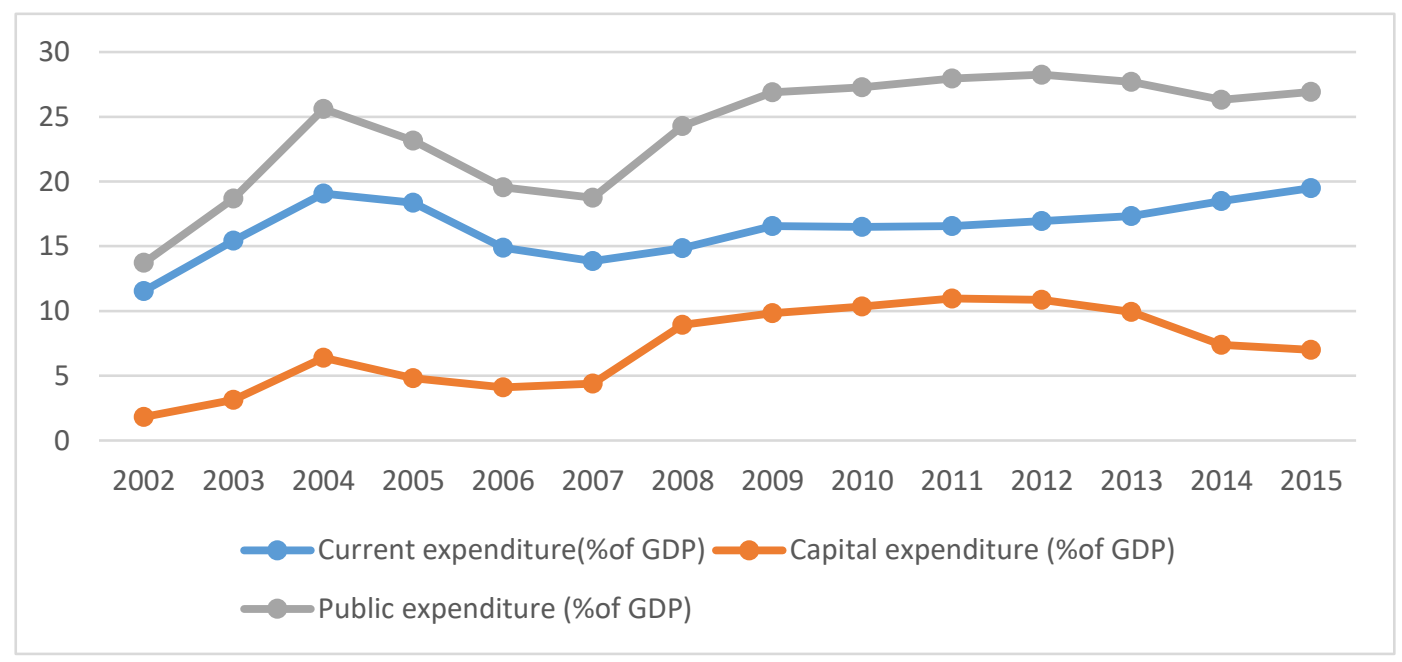

Fig. 1. Public expenditures, \% GDP.

Source: Macroeconomics Department, Ministry of Finance. Processed data.

Figure 1 demonstrates that there is an upward trend of the overall budget expenditures as a share of GDP. This share in 2004 was $25.6 \%$, in 2007 it was 
$19.5 \%$, while in 2009 (the financial crises) it increased by $26.5 \%$. During 2010, the share of public spending as a ratio of GDP increased to $29.9 \%$, while in 2015 it decreased to $26.91 \%$. Unlike other Western Balkan countries, public spending in Kosovo is still below the average with only $30 \%$ of GDP, whereas in Albania and Serbia public expenditure is $38 \%$ and $45 \%$, respectively. According to Fig. 1, it can be stated that despite the large difference between capital and current expenditures, the contribution of capital expenditures to economic growth has been improving from year to year, the share of total public expenditures increased from $8 \%$ in 2000 to $30 \%$ in 2015. However, current spending from 2000 to 2012 has had a downward trend.

The purpose of fiscal policy in terms of expenditure has been to reduce current spending by lowering operating costs and subsidies and leaving a greater proportion of capital spending. Specifically, it may be noted that capital expenditures have had a positive and significant impact on economic growth and also mitigated the negative effects that the global economic crisis of 2007 had throughout the region. This also confirms the conclusions reached by Bachmann \& Sims (2012) that increased public sector investment, especially in times of crisis, enhances private sector confidence as one of the pillars of economic development

\section{LITERATURE REVIEW}

There are many studies analysing the relationship between public spending and economic growth in developed and developing countries. However, there is no consistent evidence that there is an important relationship between public spending and economic growth, in a positive or negative direction. The empirical estimates of the impact of public spending on economic growth vary depending on the country (region), the methods and the tests of econometric models used, as well as the categorisation of public expenditures.

The exogenous growth theory, i.e., the basis of the neoclassical theory developed by Solow (1956) and Swan (1956), suggests that fiscal policies cannot bring changes in economic growth. In other words, changes in fiscal variables such as the level of taxes and public spending are temporary economic blows. According to Dar \& AmirKhalkhali (2002), "economic growth can only occur as a result of exogenous technological changes". Thus, according to the neoclassical theory, an expansionist fiscal policy will absorb some of the private savings to finance the budget deficit, which in turn will create a disparity between private savings and investments. Long-term consequences may cause lower levels of GDP. In response to this model of economic growth supported by Solow (1956) and Swan (1956), a new model of economic growth - called the endogenous economic growth model developed by Romer (1986) and Lucas (1988) - came to the conclusion that economic growth was due to endogenous growth factors.

The theory of endogenous growth provides us with a mechanism that fiscal policies can generate permanent effects on growth rates (Barro,1990; Barro \&Salai-Martin, 1992; Mendoza, Milesi-Ferretti, \& Patrick, 1997) and predict that the tax structure and the composition of public expenditures are influential in economic growth, because they affect the rate of savings and incentives to invest in human 
capital. According to Williamson (2006), fiscal policies can affect economic growth by changing taxes and spending. Dar \& AmirKhalkhali (2002) also pointed out that in the endogenous growth models the size of fiscal policy was a very important determinant of economic growth. It is now well accepted by many scholars that public spending as an important fiscal policy instrument can be an important determinant of economic growth if used efficiently (Gemmell, Kneller, Sanz, \& Ismael, 1999; Fölster \& Henrekson, 1999; Tanzi \& Zee, 1997; Kaas, 2003; Ghosh \& Gregoriou, 2008; Angelopoulos, Economides, \& Kammas, 2007).

Ram (1986), taking on a sample of 115 countries for the time period from 1960 to 1980 , estimated the effect of public spending on economic growth. In his model, Ram elaborated and derived the general expression of production function $Y=f(L$, $K, G)$ by incorporating the public expenditure variable $G$ and concluded that the effect of public expenditures on economic growth was positive and statistically important at least at the $1 \%$ level.

Other authors support Ram's idea that expanding public spending will promote economic growth. For example, Kormendi and Meguire (1983); Alexious (2007); Aschauer (1990); Chen and Lee (2005); Kocherlakota and Yi (1997); Wu (1994); Anyadiegwu, Danladi, Akomolafe, Olarinde (2015); Cheng and Lai (1997); Nworji, Okwu, Obiwuru, and Nworji (2012) found a positive relationship between public spending and economic growth. However, in support of this view, some other authors (Nurudeen \& Usman, 2010; Abdullah, 2000) conclude that expanding public spending provides two basic functions of economic activities, namely: protection and provision of certain public goods such as roads, education, health, defence and infrastructure. Securing these two functions decreases the cost of production, encouraging private sector investment, thus boosting economic growth. However, some authors (Sjoberg, 2003; Nizalov \& Loveridge, 2005; Barro, 1991) do not support the claim that public expenditures affect economic growth positively; instead, they proclaim that higher public expenditure may harm economic growth. An expansion of public spending beyond key functions will have a negative impact on economic growth. Beyond this function the discouraging effects such as a high level of taxes, high level of public debt, inefficient allocation of government resources, return to the scale of public capital, "rent-seeking" activities start. All of the statements above are factors that reinforce the existence of a hypothesis for a non-linear relationship between public expenditure and economic growth.

Many authors (Bergh \& Henrekson, 2011; Grier \& Tullock, 1989; Landau, 1983; Engen \& Skinner, 1992; Dar \& AmirKhalkhali, 2002; Cameron, 1982; Marlow, 1986; Conte \& Darrat, 1988; Fölster \& Henrekson, 1999; Afonso \& Furceri, 2010; Maingi, 2017) have found a negative correlation between public spending and economic growth. They suggest that expanding the size of public spending will have a negative economic growth effect, also causing the "crowdout" effect of private investment. In addition, public spending often translates into inefficient spending due to distorted resource allocation, because policymakers often effort to gain popularity and ensure the retention of power by increasing public spending on non-productive projects. Moreover, some scholars argue that increasing public spending will affect the demand for more taxes to support this 
growth. This tax expansion will hurt the economy, discouraging innovation, lowering private investment that affects the economic downturn (Chen \& Lee, 2005). Christie (2014), on the other hand, presents a nonlinear relationship through the growing effect of tax rates that are required to finance public spending and economic growth. Hence, according to Hindriks \& Myles (2006), economic activities of public sector intended to provide public goods pose a conflict between those that require higher public spending and those who demand a lower tax burden. Revising the literature for this nonlinear relationship, Lynch (2004) concludes that if taxes and expenditures are down, the positive impact of lowering tax rates is lower than the negative impact on public spending cuts, and overall the net effect is negative.

Various authors have used different indicators to discuss the level of importance of public spending on economic growth. Vedder and Gallaway (1998) have used multiple regression as a method to explain the optimum spending levels and concluded that in the US this optimum is $17.45 \%$, in Canada $21.37 \%$, in Denmark $26.14 \%$, in Italy $22.23 \%$, in Sweden $19.43 \%$, in Great Britain $20.97 \%$. All relevant studies in this area are summarised in Table 1.

Table 1. Effect of Public Expenditure on Economic Growth

\begin{tabular}{|c|c|c|c|c|}
\hline Author(s) & $\begin{array}{l}\text { Effect of public } \\
\text { expenditure on } \\
\text { economic growth }\end{array}$ & $\begin{array}{l}\text { Empirical } \\
\text { model }\end{array}$ & Countries & $\begin{array}{l}\text { Time period } \\
\text { of studies }\end{array}$ \\
\hline Landau (1983) & Negative & OLS & $\begin{array}{l}96 \text { developed } \\
\text { countries }\end{array}$ & 1960-1979 \\
\hline $\begin{array}{c}\text { Engen \& } \\
\text { Skinner (1991) }\end{array}$ & Negative & 2SLS & 107 countries & $1970-1985$ \\
\hline $\begin{array}{l}\text { Barro } \\
(1991)\end{array}$ & Negative & OLS & 98 countries & 1960-1985 \\
\hline $\begin{array}{c}\text { Fölster and } \\
\text { Henderson } \\
\text { (1999) }\end{array}$ & Negative & OLS & $\begin{array}{l}23 \text { OECD } \\
\text { countries }\end{array}$ & 1970-1995 \\
\hline $\begin{array}{l}\text { Grier \& Tullock } \\
\text { (1989) }\end{array}$ & Negative & OLS & 113 countries & 1960-1985 \\
\hline $\begin{array}{c}\text { Dar \& } \\
\text { AmirKhalkali } \\
(2002)\end{array}$ & Negative & $\begin{array}{c}\text { Random } \\
\text { coefficient } \\
\text { model }\end{array}$ & $\begin{array}{l}19 \text { OECD } \\
\text { countries }\end{array}$ & 1971-1999 \\
\hline Ram (1986) & Positive & OLS & 47 countries & 1986 \\
\hline $\begin{array}{l}\text { Kormendi and } \\
\text { Maguire (1983) }\end{array}$ & Positive & Panel & 47 countries & 1963-1976 \\
\hline Cameron (1982) & Negative & OLS & 48 countries & 1963-1976 \\
\hline Marlow (1986) & Negative & OLS & 19 countries & $1960-1980$ \\
\hline $\begin{array}{l}\text { Vedder and } \\
\text { Gallaway } \\
(1998)\end{array}$ & Positive/negative & Multi-regression & $\begin{array}{c}\text { The USA, } \\
\text { Denmark, Italy, } \\
\text { Sweden, the UK }\end{array}$ & 1947-1997 \\
\hline
\end{tabular}




\begin{tabular}{|c|c|c|c|c|}
\hline $\begin{array}{c}\text { Barro \& Sala-i- } \\
\text { Martin } \\
(1992)\end{array}$ & Negative & OLS & $\begin{array}{c}\text { Developed } \\
\text { countries }\end{array}$ & 1990,1991 \\
\hline $\begin{array}{c}\text { Devarajan, } \\
\text { Swaroop, \& Zou } \\
(1996)\end{array}$ & Negative & OLS & 48 countries & $1960-1970$ \\
\hline $\begin{array}{c}\text { Aschauer } \\
(1990)\end{array}$ & Positive & OLS & USA & $1960-1980$ \\
\hline
\end{tabular}

\section{METHODOLOGY}

The following equation (1) is based on the Keynesian and endogenous growth model (Barro, 1990; Barro \& Sala-i-Martin, 1992; Devarajan, Swaroop, \& Zou, 1996) and shows the function for impact of public expenditure on economic growth:

$$
G D P=f(G, F D I, \operatorname{Tr} T a x, E X P) .
$$

The dependent variable is GDP, as used by (Hamzah, 2011; Tang, 2001; Sinha, 1998; Albatel, 2000; Bağdigen \& Çetintaş, 2004; Ram, 1986). Independent variables are public expenditure $(G)$, foreign direct investment $(F D I)$, total budget revenue (TrTax), and export $(E X P)$. All endogenous variables are expected to have a positive effect on economic growth. In the present paper, Ordinary Least Square (OLS) method is used to estimate parameter of independent variables in equation (1) and specified as follows:

$$
G D P=\lambda_{0}+\lambda_{1} G+\lambda_{2} F D I+\lambda_{3} \operatorname{TrTax}+\lambda_{4} E X P+\varepsilon .
$$

In the model above, the constant is denoted by $\lambda_{0}$. The variable parameters are denoted by $\lambda_{n} . u_{i t}$ is the coefficient of error. Estimated coefficients from these parameters show the impact of public spending on economic growth. The OLS regression model assessment was performed only after implementation of Augmented Dickey-Fuller (ADF) unit root test, because according to Philips (1986) if the series are not stationary, $t$ and $F$ statistics do not follow standard distributions. According to Gujarati (2003), in order to have a good econometric model for OLS regression, some a priori econometric assumptions should be fulfilled, such as error term residuals should have normal distribution, there should be no multicollinearity among independent variables, variance of the error term should be constant, which is known as the principle of homoscedasticity, and there should be no correlation among residuals. Therefore, due to the need to fulfil these assumptions the authors of the research performed all tests in order to make sure that their model is not spurious.

\section{EMPIRICAL ANALYSIS}

The purpose of the unit root tests is to make sure that the data are valid and reliable for further analysis. All variables with time series in the model should be stationary. If the variables are not stationary, it means that the standard assumptions 
for an asymptotic analysis are not valid. Granger and Newbold (1974), Samudram and Vaithilingam (2008) stated that with the existence of non-stationary variables the OLS model would lead to spurious estimates. To ensure that the time series data are stationary or nonstationary, the authors of the research run the following standard regression:

$$
\Delta Y_{t}=a_{0}+a_{1} y_{t-1}+\sum_{j=1}^{n} a_{1} i \Delta y_{t-1+\varepsilon_{t}},
$$

where $\Delta$ is the first difference operator and $n$ is lag, $a_{1}$ are parameters, $\varepsilon$ is a white noise error residual. According to the ADF test, these hypotheses are usually used:

$H_{0}: \gamma_{i}=0$ (series contains a unit root nonstationary);

$H_{1}: \gamma_{i} \neq 0$ (series is stationary).

To test these hypotheses, the authors of the research implemented Augmented Dickey-Fuller (ADF) Unit Root Test. Results of ADF test are presented in Table 2.

Table 2. ADF Test Results

\begin{tabular}{lcccc}
\hline Variable & Level & $\boldsymbol{p}$-value & First difference & $\boldsymbol{p}$-value \\
\hline GDP & -1.728 & 0.395 & -4.317 & 0.008 \\
$G$ & -0.828 & 0.776 & -2.892 & 0.023 \\
TrTax & 0.074 & 0.949 & -3.767 & 0.019 \\
FDI & -3.037 & 0.057 & -4.745 & 0.004 \\
EXP & -0.772 & 0.792 & -3.629 & 0.026 \\
\hline
\end{tabular}

Source: Created by the authors.

Table 2 shows that all the series are turned into stationary. Furthermore, after the first difference, all the $p$-values for all variables are significant at $5 \%$, meaning that hypothesis $H_{0}$ is rejected and the alternative hypothesis $H_{1}$ is accepted. Therefore, since all the series were stationary in the first difference it was possible to evaluate the regression analysis. Hence, test for the unit roots was the primary task before conducting OLS analysis.

\subsection{Specification of the Model}

Regression analysis was performed to find out how the change in GDP in Kosovo over the years could be explained by explanatory variables such as public expenditure $(G)$, total budget revenue $(\operatorname{Tr} T a x)$, foreign direct investment $(F D I)$, export $(E X P)$. The data cover the time period of 2002-2015. To estimate the regression coefficients, the authors of the research used the Eviews 9 statistical program. The general formulation of the estimated model is given by the following function in equation (2).

By OLS data processing with equation (2), the following results were generated: 
Table 3. Regression Coefficients of the Best Fitted First Model

\begin{tabular}{llll}
\hline Variables & $\begin{array}{l}\text { Model A1 } \\
\text { coefficient }\end{array}$ & $\begin{array}{l}\text { Model B1 } \\
\text { coefficient }\end{array}$ & $\begin{array}{l}\text { Model C1 } \\
\text { coefficient }\end{array}$ \\
\hline Constant & $2.16 \cdot 10^{9}$ & $1.89 \cdot 10^{9}$ & $2.06 \cdot 10^{9}$ \\
$G$ & 1.962 & 4.492 & 6.434 \\
& 1.479 & 1.575 & 2.072 \\
$\operatorname{TrTax}$ & 1.382 & 1.644 & $3.522^{* *}$ \\
& 0.724 & 0.820 & - \\
$F D I$ & 0.540 & 0.670 & - \\
& -518 & - & - \\
$E X P$ & -0.271 & - & - \\
& 5.828 & 5.365 & 6.276 \\
\hline$R^{2}$ & 1.935 & $2.282^{*}$ & $3.365^{* *}$ \\
\hline Durbin-Watson & 0.965 & 0.965 & 0.963 \\
\hline$F$-statistics & 1.48 & 1.40 & 1.37 \\
\hline
\end{tabular}

Note: figures in italics show the value of $t$-statistics.

$* p$-value $<0.05$

$* * p$-value $<0.01$

The coefficients obtained in the regression analysis from Table 3 show that all explanatory variables except $F D I$ are positively correlated with $G D P$ as a dependent variable. However, none of the explanatory variables presented in the first model (Table 3) were statistically relevant for the explanation of the GDP variation. Therefore, the first model was further simplified using backward elimination procedure to select the best-fitted model for the data set. First, the authors of the research excluded $F D I$, which was statistically irrelevant and posed a negative effect, as was not expected in theory, but all this could be explained by the fact that $F D I$ in Kosovo was small in relation to the overall GDP. Another possible reason might be the inefficient allocation of such investments. From the B1 model the authors of the research excluded the amount of total budget revenues (TrTax), which had a positive impact on economic growth, but as a variable proved to be statistically insignificant. Model $\mathrm{C} 1$ was chosen as the best-fitted model in the regression analysis and showed that the public expenditure $(G)$ was positively correlated and significantly determined the variation of GDP in Kosovo. The coefficient value of 2.072 indicates that the increase of EUR 1 in total public spending will bring a GDP growth of EUR 2.072 while keeping the other explanatory variable $(E X P)$ in a model constant. Public expenditures were also statistically significant and positively affected economic growth. These results are the same with many theories claimed above for their positive effect. The impact of exports on GDP has been shown to be even higher, indicating that EUR 1 of export will yield a GDP growth of EUR 6.276. The coefficient of determination is relatively high (95\%) indicating that the change of GDP in Kosovo is explained largely by the change in the amount of public spending and the level of export. 
According to (Gujarati, 2003), in order to have a good econometric model for OLS regression, the model must meet certain econometric assumptions, such as the distribution of the variance of the error terms should be constant, which in econometric terms means homoscedasticity. The variance of the error terms $e_{t}$, conditioned by the variable $X$, should be the same for each $t$ and denote $\operatorname{Var}\left[e_{t} I X\right]=\operatorname{Var}\left(e_{t}\right) \sigma^{2}$ for $t=1,2,3, \ldots, n$. If this condition is violated, then it means that the error terms are not constant, so there is Heteroscedasticity. If the model has heteroscedasticity, the estimates obtained from this model are not good and the actual values of $t$-statistics will be smaller and, on the other hand, will increase the likelihood that hypothesis $H_{0}$ will not be rejected.

To confirm whether the residual of error terms has heteroscedasticity, hypotheses were tested:

$$
\begin{aligned}
& H_{0}: \sigma=0 \text { Constant variance (homoscedasticity); } \\
& H_{1}: \sigma \neq 0 \text { Non-constant variance (heteroscedasticity). }
\end{aligned}
$$

To test these hypotheses, Breusch-Pagan-Godfrey test was used. Results for heteroscedasticity are presented in Table 4.

\begin{tabular}{|c|c|c|c|}
\hline Test performed & Model A1 & Model B1 & Model C1 \\
\hline Breusch-Pagan-Godfrey & $\frac{3.436}{0.487}$ & $\frac{3.183}{0.364}$ & $\frac{4.438}{0.108}$ \\
\hline $\begin{array}{l}H_{0} \text { : Data shows homoscedasticity } \\
H_{1} \text { : Data shows } \\
\text { heteroscedasticity }\end{array}$ & $H_{0}$ accepted & $H_{0}$ accepted & $H_{0}$ accepted \\
\hline
\end{tabular}

Table 4. Testing Data for Heteroscedasticity

Note: The underlined figures show $R^{2}$ observed while figures in italics present the $p$-value.

According to the results of Table 4, it can be established that the $p$-value is insignificant and the null-hypothesis is accepted. According to Table 4, probability = $0.108>0.05$. This means that variance of error terms is constant (homoscedasticity) and there is no problem of heteroscedasticity.

Normality distribution of the error terms is another test that must be performed and meet certain econometric assumption before the model is being evaluated. Normality tests are used to determine whether residuals have a normal distribution or not. In the present study, to verify if the error terms have a normal distribution, the authors used the matching criterion called Jarques-Bera $(J B)$. Statistically $J B$ is as follows:

$$
J B=n\left[\frac{S^{2}}{6}+\frac{(E K)^{2}}{24}\right]
$$

The basic and alternate hypotheses used to test the normal distribution of the error terms are:

$$
\begin{aligned}
& H_{0}: \mu \sim N\left(0, \sigma^{2}\right) \text { normal distribution; } \\
& H_{1}: \mu \neq N\left(0, \sigma^{2}\right) \text { not normal distribution. }
\end{aligned}
$$

To test these hypotheses, the authors used Jarques-Bera $(J B)$ test. Results for normal distribution are presented in Table 5. 
Table 5. Normality Testing

\begin{tabular}{lccc}
\hline Test performed & Model A1 & Model B1 & Model C1 \\
\hline Jarque-Bera & 0.382 & 0.451 & 0.434 \\
& 0.825 & 0.797 & 0.804 \\
\hline$H_{0}:$ data comes from a normal & $H_{0}$ accepted & $H_{0}$ accepted & $H_{0}$ accepted \\
distribution & & & \\
$H_{1}:$ data does not come from & & & \\
a normal distribution & & & \\
\hline
\end{tabular}

Note: The values in italics present the $p$-value.

According to the results of Table 5, it can be established that the $p$-value is higher than the probability of 0.05 . According to Table 5, probability $=0.804>$ 0.05 . This means that hypotheses $H_{0}$ cannot be rejected, so the residuals of the bestfitted model have a normal distribution.

Another econometric assumption that the model must meet is that the observations of the error terms are independent of each other. Each error term observation in two different time periods should not be correlated, which implies that $\operatorname{corr}\left[e_{t}, e_{s} I X\right]=0$ for each $t \neq s$. If this assumption is violated, it can be stated that there is autocorrelation in the model. It indicates that error term observations in OLS are correlated. Autocorrelation in the context of the OLS model is a common problem when causing time series data. When autocorrelation is present, the OLS procedure still produces unbiased estimates. Therefore, the variation of error term observations may be smaller than it is in reality and, as a consequence of this variation, coefficient of determination $R^{2}$ would be much larger than it is in reality. To find out if the error term has autocorrelation, the following form is applied:

$$
e_{t}=\alpha+\rho_{1} e_{t-1}+\rho_{2} e_{t-2}+\rho_{3} e_{t-3}+\ldots+\rho_{p} e_{t-p}+\varepsilon_{t}
$$

To determine whether the error term has autocorrelation the following hypotheses are tested:

$$
\begin{aligned}
& H_{0}: \rho_{1}=\rho_{2}=\rho_{3}=\cdots=\rho_{k}=0 \text { no autocorrelation; } \\
& H_{1}: \rho_{1}=\rho_{2}=\rho_{3}=\cdots=\rho_{k} \neq 0 \text { positive autocorrelation. }
\end{aligned}
$$

To test these hypotheses, the authors used the Breusch-Godfrey method or otherwise the LM. Results for autocorrelation test are presented in Table 6.

Table 6. Testing for Autocorrelation

\begin{tabular}{lccc}
\hline Test performed & Model A1 & Model B1 & Model C1 \\
\hline Breusch-Godfrey Serial Correlation LM & 1.016 & 1.183 & 1.326 \\
& 0.601 & 0.553 & 0.515 \\
\hline$H_{0}:$ there is no serial correlation & $H_{0}$ accepted & $H_{0}$ accepted & $H_{0}$ accepted \\
$H_{1}:$ there is serial correlation & & & \\
\hline
\end{tabular}

Note: The values in italics present the $p$-value. 
According to Table 6, the result of LM test shows that the $p$-value is insignificant and the null-hypothesis is accepted. According to Table 6 , probability $=0.515>$ 0.05 . Therefore, it can be concluded that there is no autocorrelation problem in the best-fitted model.

\section{CONCLUSION}

According to the overall analysis of the performed models, it can be concluded that the models that are built are statistically important and can provide a consistent assessment of the impact of public spending on the economic growth of Kosovo. The results obtained show that out of four variables used in the estimation public spending $(G)$ and exports $(E X P)$ have a positive and statistically significant effect on economic growth, while the other two variables such as total budget revenue $(\operatorname{Tr} T a x)$ and foreign direct investment $(F D I)$ have been found to be statistically insignificant. The obtained results in the present study are consistent with many theoretical and empirical views.

One of the conclusions of the paper is that public spending positively affects economic growth and is a very important factor of Kosovo's economic development, which is compatible with the Keynesian's theory. The effect of public spending on economic growth in Kosovo has had a significant impact on achieving economic objectives. This is because Kosovo is a transitional economy where public spending is very important in the pace of economic reforms and infrastructure improvement as an important basis for private sector development.

The results of the research are very important for economic policy makers in Kosovo. The authors recommend that the government should focus on public spending as an important fiscal policy instrument to stimulate the economy and boost economic performance. Kosovo has no monetary policy, so fiscal policy is the only leverage to create an appropriate and important environment for economic reform and infrastructure development as an important basis for the development of the private sector.

Policymakers in Kosovo might increase the level of public spending to the average of the countries of the region in order to achieve macroeconomic stability. The government needs to increase investment in capital-productive products and decrease investment in unproductive expenditures.

\section{REFERENCES}

Abdullah, H. (2000). The Relationship Between Government Expenditure and Economic Growth in Saudi Arabia. Journal of Administrativ Science, 173-191.

Afonso, A., \& Furceri, D. (2010). Government Size Composition, Volatility and Economic Growth. European Journal of Political Economy, 26(4), 517-532. https://doi.org/10.1016/j.ejpoleco.2010.02.002

Albatel, A. H. (2000). The Relationship between Government Expenditure and Economic Growth in Saudi Arabia. J. King Saud Univ., Admin. Sci., 12, 179-191.

Alexious, C. (2007). Unraveking the "Mystery" Between Public Expenditure and Growt: Emperical Evidence From Greece. International Jornal of Economics, 21-31. 
Angelopoulos, K., Economides, G., \& Kammas, P. (2007). Tax-Spending Policies and Economic Growth Theoretical Predictions and Evidence From the OECD. European Journal of Political Economy, 23(4), 885-902. https://doi.org/10.1016/j.ejpoleco.2006.10.001

Aschauer, D. A. (1990). Is Governmet Spending in Stimulative? Contemporary Policy Issues, 8(4), 30-46. https://doi.org/10.1111/j.1465-7287.1990.tb00300.x

Bachmann, R., \& Sims, E. (2012). Confidence and the Transmission of Government Spending Shocks. Journal of Monetary Economics, 59(3), 235-249. https://doi.org/10.1016/j.jmoneco.2012.02.005

Bağdigen, M., \& Çetintaş, H. (2004). Causality Between Public Expenditure and Economic Growth: The Turkish Case. Journal of Economic and Social Research, 1(6), 53-72.

Barro, R. J. (1990). Government Spending in a Simple Model of Endogenous Growth. Journal of Political Economy, 98(5), 103-126.

Barro, R. J. (1991). Economic Growth and a Cross Section of Countries. The Quarterly Journal of Economics, 106(2), 407-443.

Barro, R., \& Sala-i-Martin, X. (1992). Public Finance in Models of Economics Growth. The Review of Economic Studies, 59(201), 645-661. https://doi.org/10.3386/w3362

Bergh, A., \& Henrekson, M. (2011). Government Size and Growth: A Survey and Interpretation of the Evidence. Journal of Economic Survey, 25(5), 872-897. https://doi.org/10.1111/j.1467-6419.2011.00697.x

Cameron, D. R. (1982). On the limits of the Public Economy. Annals of the Academy of Political and Social Science, 459, 46-62.

Chen, S.-T., \& Lee, C.-C. (2005). Government Size and Economic Growth in Taiwan: A Threshold Regression Approach. Jornal of Policy Modeling, 27(9), 1051-1066. https://doi.org/10.1016/j.jpolmod.2005.06.006

Cheng, B. S., \& Lai, T. W. (1997). Government Expenditures and Economic Growth in South Korea: A VAR Approach. Journal of Economic Development, 22(1).

Christie, T. (2014). The Effect of Government Spending on Economic Growth: Testing the NonLinear Hypothesis. Bulletin of Economic Reaserch, 66(2), 183-204. https://doi.org/10.1111/j.1467-8586.2012.00438.x

Conte, M. A., \& Darrat, A. F. (1988). Economic Growth and the Expanding Public Sector: A ReExamination. The Review of Economics and Statistics, 70(2), 322-330. https://doi.org/10.2307/1928317

Danladi, J. D., Akomolafe, K. J., Olarinde, O. S., \& Anyadiegwu, L. N. (2015). Government Expenditure and Its Implication for Economic Growth: Evidence From Nigeria. Journal of Economics and Sustainable Development, 6(18), 142-150.

Dar, A. A., \& AmirKhalkhali, S. (2002). Government Size, Factor Accumalation, and Economic Growth: Evidenc From OECD Countries. Journal of Policy Modeling, 24(7-8), 679-692. https://doi.org/10.1016/s0161-8938(02)00163-1

Devarajan, S., Swaroop, V., \& Zou, H. (1996). The Composition of Public Expenditure and Economic Growth. Journal of Monetary Economics, 37(2), 313-344. https://doi.org/10.1016/S0304-3932(96)90039-2

Engen, E. M., \& Skinner, J. (1992). Fiscal Policy and Economic Growth. https://doi.org/10.3386/w4223

Fölster, S., \& Henrekson, M. (1999). Growth and the Public Sector: Acritique of the Critics. Eropean Journal of Political Economy, 15(2), 337-358. https://doi.org/10.1016/s0176-2680(99)00010-5

Gemmell, N., Kneller, R., \& Sanz, I. (1999). Fiscal Policy Impacts on Growth in the OECD: Are They Long Run? Journal of Public Economics 74,, 74, 171-190.

Ghosh, S., \& Gregoriou, A. (2008). The Composition of Government Spending and Growth: Is Current or Capital Spending Better? Oxford Economic Papers, 60(3), 484-516. https://doi.org/10.1093/oep/gpn005

Granger, C. W., \& Newbold, P. (1974). Spurious regression in econometrics. Journal of Econometrics, 2(2), 111-120. https://doi.org/10.1016/0304-4076(74)90034-7 
Grier, K. B., \& Tullock, G. (1989). An Empirical Analysis of Cross-National Economic Growth,1951-1980. Journal of Monetary Economics, 24(2), 259-276. https://doi.org/10.1016/0304-3932(89)90006-8

Gujarati, D. N. (2003). Basic Econometric. McGraw-Hili Companies.

Hamzah, K. S. (2011). The Association Between Government Expenditure and Economic Growth in Malaysia.

Hindriks, J., \& Myles, G. D. (2006). Intermediate Public Economics. MIT Press.

IMF. (2015). Government Finance Statistics Manual. New York: International Monetary Fund.

Kaas, L. (2003). Productive Government Spending, Growth, and Sequential Voting. European Journal of Political Economy, 19(2), 227-246. https://doi.org/10.1016/s0176-2680(02)00168-4

King, J. E. (2012). Post Keynesian Economics. Northampton: Edward Elgar Publishing.

Kocherlakota, N. R., \& Yi, K.-M. (1997). Is There Endogenous Long Run Growth? Evidence From the United States and the United Kingdom. Journal of Money, Credit and Banking, 29(2), 235262. https://doi.org/10.2307/2953677

Kormendi, R. C., \& Meguire, P. (1983). Government Debt, Government Spending, and Private Sector Behavior. The American Economic Review, 73(5), 994-1010.

Landau, D. (1983). Government Expenditure and Economic Growth: A Cross-Country Study. Southern Economic Journal, 49(3), 783-792. https://doi.org/10.2307/1058716

Lynch, R. G. (2004). Rethinking Growth Strategies: How State and Local Taxes and Services Affect Economic Development. Washington DC: Economic Policy Institute.

Lucas, R. E. (1988). On the Mechanics of Economic Development. Journal of Monetary Economics, $22,3-42$.

Maingi, J. N. (2017). The Impact of Government Expenditure on Economic Growth in Kenya: 19632008. Advances in Economics and Business, 5(12), 635-662. https://doi.org/10.13189/aeb.2017.051201

Marlow, M. L. (1986). Private Sector Shrinkage and the Growth of Industrialized Econimies. Public Choice, 49(2), 143-153. https://doi.org/10.1007/bf00181036

Mendoza, E. G., Milesi-Ferretti, G. M., \& Patrick, A. (1997). On the Ineffectiveness of Tax Policy in Altering Long-Run Growth: Harberger's Superneutrality Conjecture. Journal of public Economics, 66(1), 99-126. https://doi.org/10.1016/s0047-2727(97)00011-X

Nizalov, D., \& Loveridge, S. (2005). Regional Policies and Economic Growth: One Size Does Not Fit All. The Review of Regional Studies, 35(3), 266-290.

Nurudeen, A., \& Usman, A. (2010). Governmeent Expenditure and Economic Growth in Nigeria, 1970-2008: A Disaggregate Analysis. Bussines and Economics Journal, 1-11.

Nworji, I. D., Okwu, A. T., Obiwuru, T. C., \& Nworji, L. O. (2012). Effects of Public Expenditure on Economic Growth in Nigeria: A Disaggregated Time Series Analysis. International Journal of Management Sciences and Business Research, 1(7), 1-15.

Philips, P. C. (1986). Understanding Spurious Regressions in Econometrics. Journal of Econometrics, 33(3), 311-340. https://doi.org/10.1016/0304-4076(86)90001-1

Ram, R. (1986). Government Size and Economic Growth: A New Framework and Some Evidence from Cross-Section and Time-Series Data. The American Economic Review, 76(1), 191-203.

Romer, P. M. (1986). Increasing Returns and Long-Run Growth. The Journal of Political Economy, 94(5), 1002-1037. https://doi.org/10.1086/261420

Samudram, M., Nair, M., \& Vaithilingam, S. (2008). Keynes and Wagner on Government Expenditures and Economic Development: The Case of a Developing Economy. Empirical Economics, 36(3), 697-712. https://doi.org/10.1007/s00181-008-0214-1

Sinha, D. (1998). Economic Growth and Government Expenditure in China. MPRA Paper 18347, University Library of Munic.

Sjoberg, P. (2003). Government Expenditure Effect on Economic Growth: The Case of Sweden 1960-2001. (Bachelor's Thesis).

Slemrod, J., Gale, W. G., \& Easterly, W. (1995). What Do Cross-Country Studies Teach About Government Involvement, Prosperity, and Economic Growth. Brookings Papers on Economic Activity, 1995(2), 373-431. https://doi.org/10.2307/2534615

Solow, R. M. (1956). A Contribution to the Theory of Economic Growth. The Quartely Journal of Economics, 70(1), 65-94. 
Stiglitz, J. E., \& Atkinson, A. B. (1980). Lecture on Public Economics. New York: McGrave-Hill.

Swan, T. W. (1956). Economic Growth and Capital Accumulation. Economic Record, 32(2), 334361. https://doi.org/10.1111/j.1475-4932.1956.tb00434.x

Tang, T. C. (2001). Testing the Relationship Between Government Expenditure and National Income in Malaysia. Analisis, 8(1-2), 37-51.

Tanzi, V. (1997). The changing Role of the Sate inthe Economy: A Historical Perspective. IMF Working Paper, 97-114.

Tanzi, V., \& Zee, H. H. (1997). Fiscal Policy and Long-Run Growth. Staff Papers - International Monetary Fund, 44(2), 179-209.

Vedder, R. K., \& Gallaway, L. E. (1998). Government Size and Economic Growth. Joint Economic Committee.

Williamson, S. D. (2006). Macroeconomics. Pearson Education.

Wu, X. (1994). Government Expenditure and Economic Growth: Evidence From China 1952-2000.

\section{AUTHORS`SHORT BIOGRAPHIES}

Lekë Pula was born in 1984 in Prishtina. He received the Bachelor's degree in Economics from the Faculty of Economics, University of Prishtina, in 2006, and the Master's degree in Economics, in 2010. He is a PhD student majoring in economics at the University of Prishtina. Currently he is in the process of defending his Doctoral Thesis "The Role of Public Sector Performance in Increasing the Economic Efficiency".

Since 2007, he has been an Assistant at the private higher education institution Iliria International College. Since 2010, he has been an Assistant at the Faculty of Economics, University of Prishtina. $\mathrm{He}$ is engaged in the fields of microeconomics and accounting. Leke Pula is the author of several research papers in microeconomics, energy economics and small business economics.

ORCID iD: https://orcid.org/0000-0002-4540-7635

Alban Elshani was born in 1981 in Prishtina. He received the Bachelor's degree in Banking, Finance and Accounting from the Faculty of Economics, University of Prishtina, in 2005, and the Master's degree in Economics, in 2010. In May 2018, he defended his Doctoral Thesis "The Effect of Linear and Progressive Taxation in Economic Growth: A Cross-country Comparative Study".

Since 2010, he has been an Assistant at the Faculty of Economics, University of Prishtina. He is engaged in the fields of managerial accounting, tax accounting and taxation strategy. He is a Lecturer of Public Finance at the Department of Financial Mathematics at the Faculty of Natural and Mathematical Sciences.

Alban Elshani is the author of several research papers in taxation policy, economic growth models, and financial and tax accounting.

ORCID iD: https://orcid.org/0000-0002-8917-6138 